\title{
Application of Problem Based Learning Model Using Education for Sustainable Development Context in Improving Critical Thingking Ability for Junior High School Students at Heat Theory
}

\author{
Jenit Anggiani Lutfianis ${ }^{1 *}$, Agus Fany Chandra $^{1}$, Purwanto ${ }^{1}$ \\ ${ }^{1}$ Universitas Pendidikan Indonesia, INDONESIA \\ Received 08 th January 2020 - Revised 24th January 2020 - Accepted $10^{\text {th }}$ March 2020
}

\begin{abstract}
Indonesia ranks $6^{\text {th }}$ from the bottom based on four annual studies Trends in International Mathematics and Science Study (TIMSS) in 2015. Based on the results of the TIMSS and PISA, it was said that Indonesian students only mastered low-level questions and lacked high-level questions (HOTS) which included requiring students to think analytically, creatively and critically. Therefore, this study aims to improve students critical thinking skills with the Problem Based Learning model using the education of sustainable development (ESD) context on the heat theory. This study used a one group pretest-posttest design with a sample of 31 students from one of junior high schools in Bandung city. The instrument used was a critical thinking ability test and sustainability awareness profile questionnaire. The acquisition of $<\mathrm{g}>$ shows the ability to think critically: Provide a basic explanation of 0.72 ; build basic skills 0.69; concluded 0.69; make further explanation 0.47; and set the strategy and tactics 0.38 . Obtaining sustainability awareness questionnaire $63.33 \%$ with the category "practice that are done" based on this, it can be concluded that the problem based learning model using ESD context can be used to improve students' critical thinking skills.
\end{abstract}

Keywords: Problem Based Learning, Education for Sustainable Development, Critical Thinking Ability, Sustainability Awareness

\section{INTRODUCTION}

In this 21st century, science and technology become an important foundation for the progress of a nation. Critical, creative, collaborative and communicative attitudes become the main skills in life [1]. Learning at school must be able to train students to be ready to live life in the future. The ability of critical thinking is one of the high-level skills that is believed to play an important role in thinking logically, making decisions, and solving problems [2]. In 21 st century education, there are three core concepts in education, namely; 1) life and career skills, 2) learning and innovation skills, 3) Information, median and technology skills. Three concepts of the $21^{\text {st }}$ century have been adapted by the Ministry of Education and Culture of the Republic of Indonesia, which was developed for education towards creative Indonesia in 2045 which was realized through basic competencies [3]

Based on the 2013 Revised Curriculum listed in Permendikbud No. 24 of 2016 for the Elementary and Secondary Education Unit in the current physics subject, students are expected to have competencies, one of which is to live a positive attitude with critical, creative, innovative, and collaborative thinking, accompanied by honesty and openness, based on the potential of the process and physics product [4].

Based on the results of TIMSS and PISA it is said that Indonesian students only master low-level 
questions that are routine, simple computation, and measure knowledge of everyday facts [5]. Indonesian students lack mastery of high-level questions (HOTS) which among them require students to think analytically, creatively and critically [6]. In addition, also stated in their research that students' critical thinking skills were in the low category. In Putranto research explained that of the six indicators of critical thinking skills, five of them showed that students' critical thinking abilities were still low [7].

In 2002 in Johannesburg, UNESCO officially gave rise to the concept of ESD (Education for Sustainable Development) in education. Education is expected to insert this ESD context as an effort to overcome the negative impacts of sustainable development. Learning using the ESD context directs students to: learn to ask critical questions (critical thinking), learn to clarify one's values, learn to imagine a more positive and sustainable future, learn to think systematically, and others [8].In 2002 in Johannesburg, UNESCO officially gave rise to the concept of ESD (Education for Sustainable Development) in education. Education is expected to insert this ESD context as an effort to overcome the negative impacts of sustainable development. Learning using the ESD context directs students to: learn to ask critical questions (critical thinking), learn to clarify one's values, learn to imagine a more positive and sustainable future, learn to think systematically, and others [8]. Every problem solving ability faced by students is expected to always insert 3 ESD pillars namely: economic, environmental, and social culture [9]. It is this context of ESD which wants that everyone can feel the benefits of education in everyday life (values, habits, and lifestyle) that are needed for a sustainable future and change society to be more positive .

Based on these problems, we need a solution or innovation in learning that can help students to improve their critical thinking skills. In this connection, we need a physics learning innovation that can improve students critical thinking skills. These innovations can be in the form of improvements in various ways such as the learning model [10]. State that the problem solving learning model is designed to solve various problems or problems in a learning which ultimately requires students to think critically and analytically so that they are able to construct new knowledge. Therefore, the aim of the research is to improve the critical thinking skills of junior high school students on heat theory.

\section{MATERIAL AND METHODS}

\section{Methods}

Research to be conducted is quantitative research using several research instruments in measuring the results obtained. The research method used was a quasi-experimental method with one group pretest-posttest design. The research design can be presented schematically as follows:

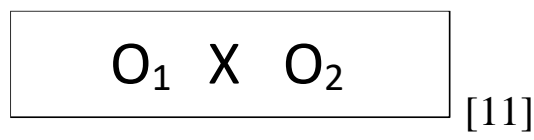

\footnotetext{
$\mathrm{O}_{1} \quad=$ Pretest on a critical thinking skills test

$\mathrm{X}=$ Treatment Problem Based Learning Using the ESD context

$\mathrm{O}_{2} \quad=$ Posttest on a critical thinking skills test
}

In this research design, students are first given a pretest then given treatment in the form of learning activities and at the end of the activity, students are given a posttest. This is in accordance with the research objectives to be achieved, namely to find out the improvement of students' critical thinking skills after being treated in the form of Problem Based Learning (PBL) models. The subjects studied were 31 junior high school class students from one of the state junior high schools in Bandung.

To find out the results of increasing students' critical thinking skills through the Problem based learning model using the ESD context, a normalized gain score calculation is performed from the initial and final tests. Normalized gain scores $<\mathrm{g}>$ can be expressed in the following equation:

$$
\langle\mathrm{g}\rangle=\frac{s_{\text {pos }}-s_{\text {pre }}}{S_{\text {mak }}-s_{\text {pre }}}
$$

Where $S_{\text {pos }}$ is a posttest score, is a pretest score, $S_{\text {mak }}$ is an ideal score. Interpretation of the normalized gain value shown in the Table 1. 
Table 1. Interpretation of the normalized gain value [12]

\begin{tabular}{ll}
\hline \multicolumn{1}{c}{ Score $<\mathrm{g}>$} & Category \\
\hline$<\mathrm{g}>\geq 0,7$ & High \\
\hline $0,7><\mathrm{g}>\geq 0,3$ & Medium \\
\hline$<\mathrm{g}><0,3$ & Low
\end{tabular}

Sustainability Awareness questionnaire in the form of a questionnaire with 15 statements adopted from a journal entitled "The status on the level of environmental awareness in the concept of sustainable development among secondary school students" [13]. The results of this questionnaire were processed using the Guttman scale.

On this Guttman scale the answer can be made the highest score of one and the lowest score of zero, for answers yes given a score of 1 and the answer is not given a score of 0 . Then the data is made in the form of a percentage. as follows:

$$
\text { Percentage }(\%)=\frac{\text { total score obtained }}{\text { total score } \text { maximum }} \times 100 \%
$$

obtaining the results using the Guttman scale, to profile sustainability awareness is classified based on the criteria in Table 2.

Table 2. The percentage sustainability awareness [13]

\begin{tabular}{cl}
\hline $\begin{array}{c}\text { Persentase sustainability } \\
\text { awareness }\end{array}$ & \multicolumn{1}{c}{ Meaning } \\
\hline $0,0 \%-50,0 \%$ & $\begin{array}{l}\text { Practices that seldom or dislike to be } \\
\text { done }\end{array}$ \\
\hline $51,0 \%-70,0 \%$ & $\begin{array}{l}\text { Practices that are done/happened } \\
\text { moderate/ medium }\end{array}$ \\
\hline $71,0 \%-100,0 \%$ & $\begin{array}{l}\text { Practices / feelings that are most } \\
\text { likely one/ happende }\end{array}$ \\
\hline
\end{tabular}

\section{Instrument}

The instruments used in this study were tests of critical thinking skills and the Sustainability Awareness questionnaire. Critical thinking skills test in the form of eight essay questions related to heat material. The eight questions are divided into several indicators of critical thinking skills. There are five indicators of critical thinking skills used in this study, that is: (1) providing basic explanations, (2) building basic skills, (3) concluding, (4) making further explanations, (5) managing strategies and tactics [14].

\section{RESULTS AND DISCUSSION}

The improvement of critical thinking ability is done by calculating the normalized gain value from the pretest score and posttest score of students' critical thinking ability test (attachment). For the pretest test, Critical Thinking ability obtained a minimum score $\left(X_{\min }\right)$ of 3 , a maximum score $\left(X_{\text {maks }}\right)$ of 7 , while for the posttest a minimum score $\left(X_{\min }\right)$ of 10 , a maximum score $\left(X_{\min }\right)$ of 24 . Following a recapitulation of the pretest score and posttest score Critical Thinking Ability test as in Table 3. 
Table 3. Recapitulation of the pretest score and posttest score critical thinking ability

\begin{tabular}{ccccccc}
\hline Test & $\left(\mathrm{X}_{\text {ideal }}\right)$ & $\left(\mathrm{X}_{\text {min }}\right)$ & $\left(\mathrm{X}_{\text {min }}\right)$ & $\left(\mathrm{X}_{\text {rata }}{ }^{2}\right)$ & $<\mathrm{g}>$ & Category \\
\cline { 1 - 5 } pretest & 26 & 3 & 7 & 6.51613 & 0.57 & Medium \\
\cline { 1 - 5 } & 26 & 10 & 24 & 17.5806 & & \\
\hline
\end{tabular}

Table 4.1 it can be seen that the normalized gain value of the critical thinking ability test is 0.57 with the medium category according to the criteria set by Richard R Hake [12]. This normalized gain value shows that an increase in students critical thinking skills after the implementation of the Problem Based Learning model using the ESD context in learning. This shows that students critical thinking skills have generally increased in the medium category.

The recapitulation results of the pretest score and posttest score of students' critical thinking skills can also be illustrated in Figure 1.

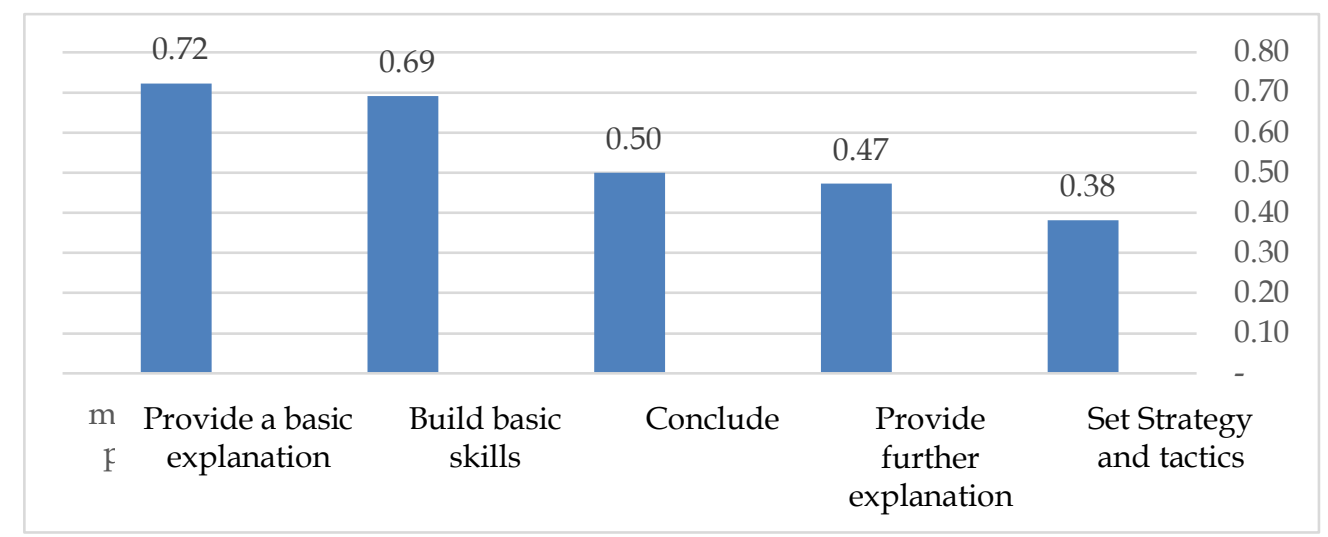

Figure 1. Bar diagram $<\mathrm{g}>$ aspects of students critical thinking abilities

Figure 1 indicates the highest gain score is found in critical thinking skills in Elementary Clarification, whch is 0.72 which can be categorized as high category. Increased critical thinking skills for each subability to provide a basic explanation that is analyzing arguments and asking and answering. This means that the critical thinking ability test provides basic explanations that the average answer correctly by students.

Increased critical thinking skills provide a basic explanation trained when students are given stimulation, observing, reasoning and questions and answer questions when learning takes place by applying the Problem Based Learning model. As research on [7]. that an increase in critical thinking skills provides a basic explanation develops when students are given stimulation and are trained to observe, ask questions, and reason during the learning process.

A score of $<\mathrm{g}>$ critical thinking builds average abilities of 0.69 , including in the medium category. It means that when conducting experiments, students work together in groups and observing experiments can practice critical thinking skills sub building basic abilities. Like research conducted by Putranto (2014) the improvement of developing basic abilities develops because when students conduct experiments by observing experiments related to material conducted in groups.

The ability to think critically concluded at 0.50 included in the medium category. It shows that when students process data or information from the results of the experiment and discuss with group members to conclude the results of experiments that have been carried out can improve the ability to conclude students. In line with research from [7]. that the ability to conclude develops when students discuss with their group friends.

The gain score of critical thinking ability makes further explanation of 0.47 included in the medium category. This can be achieved by training students to analyze experimental data, further identifying experimental data to support answering questions so as to obtain new information. It is also in accordance with Putranto's research to improve the ability to make further explanations during the learning process, encouraged to carry out further identification of the data obtained by answering questions given to the worksheet, so students get new information [7]. 
The gain score of critical thinking skills governs strategy and tactics by 0.38 in the medium category. In general, the improvement of critical thinking skills makes organizing strategies and tactics trained when students make objects from existing materials by applying the concept of heat transfer. Students are given a problem and must be able to solve it, in the right way. But students still have difficulty in doing an action that is associated with the concept of heat transfer. This can be seen from the reports made by students (attachments), students only know how to make these objects, but many do not know how the concepts are in the designed objects, so the answers from the reports that students give are not in accordance with the expected answers.

Based on the data obtained, the value of N-Gain for each student is positive and there is also no NGain value which scores zero " 0 ", so it can be said that there are no students who have low critical thinking skills and no students who have not experienced an increase critical thinking skills after participating in learning using the Problem Based Learning model using the ESD context. Based on the division of criteria for the N-Gain score according to Hake, it can be said that each student experiences a variety of improvements, there are students who experience an increase that is low, medium, or high [15]. Figure 4.2 presents a diagram of the percentage of students in the N-Gain score criteria.

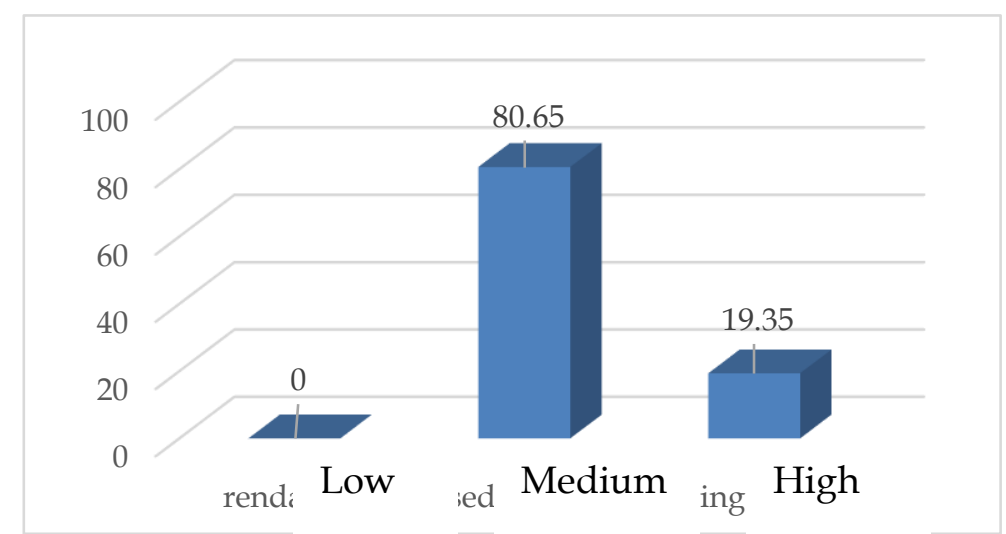

Figure 4.2 diagram of the percentage of the number of students against the criteria $<\mathrm{g}>$

From Figure 4.2 presents a diagram of the percentage of students who experience an increase in diverse critical thinking skills, but the average student $(80.65 \%$ students) experienced a moderate increase, the percentage of students who experienced a high increase of $19.35 \%$, and for those who experienced there is no increase in critical thinking skills.

Based on the recapitulation of the ESD Awareness questionnaire, the percentage obtained of students who have an awareness of education for sustainable development (ESD Awareness) is 63\% with the interpretation of Practices that are done /happened moderate/medium according [13] . It can be said that students have practiced continuing education but this happens only occasionally, and is categorized as "medium".

Table 4.2: Questionnaire Results Profile Sustainability awareness

\begin{tabular}{cc}
\hline Category & Percentage (\%) \\
\hline $\begin{array}{c}\text { Practices that seldom or } \\
\text { dislike to be done }\end{array}$ & 57 \\
\hline $\begin{array}{c}\text { Practices that are } \\
\text { done/happened moderate/ } \\
\text { medium }\end{array}$ & 63 \\
\hline $\begin{array}{c}\text { Practices / feelings that are } \\
\text { most likely one/ happened }\end{array}$ & 70 \\
\hline Average & 63,33 \\
\hline
\end{tabular}


Based on the findings in the field, it was found that the percentage of students who had an awareness of education for sustainable development (ESD Awareness) was 63\%. The sustainability awareness profile is divided into 3 categories namely Sustainability practice awareness, Behavioral and attitude awareness and Emotional awareness. For the first category of sustainability practice awareness the percentage of student responses to the behavior was $57 \%$, which means that it was done by students. Whereas for the second category behavioral and attitude awareness percentage of student responses by $63 \%$ which means that has been done by students. Likewise for the third category, namely emotional awareness, it is often done because student responses are $71 \%$, which means that it is always done by students.

Based on table 3.2 Sustainability Awareness is grouped into 3 categories. The first category, namely Sustainability practice awareness, the results obtained indicate that the behavior is rarely performed by the majority of students with a percentage of $46 \%$, while for students who perform the behavior by $57 \%$. With this, it can be concluded that students have carried out awareness practices. Sustainability practice awareness has been carried out by students such as discussing environmental issues with friends, composting leftovers into fertilizer, not using plastic bags to wrap things, discussing environmental problems with families and also following environmental awareness activities at school to overcoming environmental problems is very rarely done by students based on the questionnaire they fill out. This behavior is a characteristic of the attitude that will be shown if someone already understands the concept of sustainability.

The second category is Behavioral and attitude awareness or the behavior and attitudes of caring for the environment of the total number of students can be said that $63 \%$ of students do the behavior and $43 \%$ of students do not do the behavior. So it can be concluded that the behaviors and attitudes that care about the environment (Behavioral and attitude awareness) owned by students are classified as moderate. Behavioral and attitude awareness or behavior and attitude to care for the environment have been done by students such as reading environmental issues in the mass media, respecting biodiversity, caring for motor vehicle fumes, recycling household waste, not turning on lights in the daytime and reducing the use of clean water is often done or most likely to occur in life. This is the behavior and attitude shown when someone cares and is aware of the importance of the environment.

The third category is Emotional awareness or concern for the environment emotionally, including attitudes or behaviors that are always carried out by all students, seen in table 4.2 the percentage of students who have an Emotional awareness of $71 \%$, emotionally students have a high concern for their environment. Concern for the environment emotionally such as feeling concerned with environmental issues, feeling disappointed with the pollution in the air and rivers and aware of human responsibility towards the environment owned by students. So that Sustainability awareness or students' sustainable awareness based on the best category only cares about the environment emotionally and their care is rarely shown by their attitude, let alone being continuously carried out. So it can be concluded that based on 3 categories of Sustainability Awareness students only have awareness of the value of sustainability at the emotional level without practicing it.

In everyday life shown with the greatest value with the behavior never do it in the category of Sustainability practice awareness. Can be seen from the three categories in the awareness of students practicing sustainability does not differ too much, only a few students who begin to share with each other about the importance of sustainable development, so it still needs to be developed.

\section{CONCLUSION}

Based on data from research, processing and analysis of research data, researchers can conclude that in general the Problem Based Learning model using the ESD context can improve critical thinking skills and build a student's sustainability awareness profile, in more detail will be explained as follows:

1. Students' critical thinking skills after applying the Problem Based Learning (PBL) model using the context of ESD (Education for Sustainable Development) obtained an average pretest-posttest value of 0.57 in the medium category.

2. Student sustainability awareness profile which is divided into 3 categories, namely Sustainability practice awareness with a percentage of $57 \%$ has been done, Behavioral and attitude awareness percentage of $63 \%$ has been done and Emotional awareness with a percentage of $70 \%$ is often done by students. 


\section{REFERENCES}

[1] S. F. Rachmawati. (2011). Application of Project-Based Learning to Improve Scientific Thinking Skills and Scientific Critical Thinking of High School Students in Firmness Material Equilibrium," Jurnal Wahana Pendidikan Fisika, 16(2), 85-92

[2] Butler, H. A. (2012). Halpern Critical Thinking Assessment predicts real-world outcomes of critical thinking. Applied Cognitive Psychology, 26(5), 721-729.

[3] Murti, K. E. (2013). 21st Century Education and Its Implementation in Vocational School Learning for Interior Design Expertise Packages. Artikel Kurikulum.

[4] Education and Culture of the Republic of Indonesia, 2016.Regulation of the Minister of No. 24 of 2016 concerning Competency Standards for Primary and Secondary Education Units, Jakarta: Ministry of National Education,

[5] N. Syamsul Hadi, "TIMSS Indonesia," Prosiding Seminar Nasional dan Call For Papers Universitas Siliwangi, p. 562, 2019.

[6] Abdilah, Y. (2017). Application of the Problem Solving Laboratory learning model to improve critical thinking skills of students in Dynamic Fluid material (Doctoral dissertation, UIN Sunan Gunung Djati Bandung).

[7] Nurhasanah, N., \& Djukri, D. (2019). The effectiveness of discovery learning model with brainstorming on the critical thinking ability of students. Jurnal Pendidikan: Teori, Penelitian, dan Pengembangan, 4(5), 593 - 599. doi: http://dx.doi.org/10.17977/jptpp.v4i5.12417

[8] Tilbury, D. (2011). Education for sustainable development: An expert review of processes and learning.

[9] Rieckmann, M. (2017). Education for sustainable development goals: Learning objectives. UNESCO Publishing.

[10] Iding, I., Sudjarwo, S., \& Darsono, D. (2017). Differences in Critical Thinking between Problem Solving and Posing Models according to Student Attitudes. Jurnal Studi Sosial, 5(1).

[11] Sugiyono, (2013). Educational Research Methods, Bandung: Alfabeta,

[12] Hake, R. R. (1998). Interactive-engagement versus traditional methods: A six-thousand-student survey of mechanics test data for introductory physics courses. American journal of Physics, 66(1), 64-74.

[13] Noordin, T. A., \& Sulaiman, S. (2010). The status on the level of environmental awareness in the concept of sustainable development amongst secondary school students. Procedia-Social and Behavioral Sciences, 2(2), 1276-1280.

[14] Ikuenobe, P. (2001). Teaching and assessing critical thinking abilities as outcomes in an informal logic course. Teaching in Higher Education, 6(1), 19-32.

[15] Segara, N. B. (2015). Education for sustainable development (ESD) sebuah upaya mewujudkan kelestarian lingkungan. SOSIO-DIDAKTIKA: Social Science Education Journal, 2(1), 22-30. 